\title{
Influence of pretreatment severity on structural changes, lignin content and enzymatic hydrolysis of sugarcane bagasse samples
}

\author{
Michel Brienzo a, b, ", Simphiwe Fikizolo a, Yuda Benjamin ${ }^{a}$, Luvuyo Tyhoda ${ }^{c}$, \\ Johann Görgens ${ }^{a}$ \\ ${ }^{a}$ Department of Process Engineering, University of Stellenbosch, Private Bag X1, Stellenbosch 7602, South Africa \\ ${ }^{\mathrm{b}}$ Bioenergy Research Institute (IPBEN), University of São Paulo State (UNESP), Rua 10, $n^{\circ}$ 2527, Rio Claro, SP CEP 13500-230, Brazil \\ ${ }^{\mathrm{c}}$ Department of Forest and Wood Science, University of Stellenbosch, Private Bag X1, Stellenbosch 7602, South Africa
}

\section{A R T I C L E I N F O}

\section{Article history:}

Received 18 January 2016

Received in revised form

18 November 2016

Accepted 16 December 2016

Available online 18 December 2016

\section{Keywords:}

Bioethanol

Accessibility

Sugarcane bagasse

Degree of polymerization

Crystallinity index

Lignin content

\begin{abstract}
A B S T R A C T
The structural changes, lignin content and enzymatic hydrolysis of dilute acid pretreated bagasse from 19 varieties of sugarcane were investigated. Chemical compositions varied significantly between the materials. Glucose yield after enzymatic hydrolysis also differed significantly among the samples. The differences in glucose yields were not eliminated by increasing the pretreatment severity. Glucose yield showed a positive correlation with total dye and orange dye adsorption, whereas with blue dye adsorption it showed a weak correlation. The crystallinity index increased with the increasing pretreatment severity as a result of the removal of the amorphous components of the biomass. The degree of polymerization decreased with the increase in pretreatment severity. However, the change in either crystallinity index or degree of polymerization did not correlate with glucose yield. The results suggest that the lignin modification/reallocation is a key factor for improving cellulose accessibility of sugarcane bagasse.
\end{abstract}

๑ 2016 Elsevier Ltd. All rights reserved.

\section{Introduction}

Bioethanol represents an important biomass-derived fuel, which can be produced via the biochemical conversion of lignocellulosic biomass. Lignocellulosic biomass materials such as crop residues, sawdust, wood chips, grasses, waste paper and municipal solid waste can be used for bioethanol production. The bioethanol produced from lignocellulosic materials is named as second-generation $(2 \mathrm{G})$ ethanol or cellulosic ethanol, while first generation ethanol is produced from sucrose (juice extracted from sugarcane, sugarbeet or sweet sorghum) or starch (typically extracted from grains). Typically, bioethanol can be produced in a four step process, i.e. pretreatment, enzymatic hydrolysis, fermentation and distillation [1], where hydrolysis and fermentation may be combined. However, the recalcitrance of lignocellulosic material hinders the effectiveness of the pretreatment and enzymatic hydrolysis steps.

Lignocellulosic biomass is made up of three main components, lignin, cellulose and hemicelluloses, which are interlinked and

\footnotetext{
* Corresponding author. Bioenergy Research Institute (IPBEN), University of São Paulo State (UNESP), Brazil.

E-mail address: mbrienzo@ipben.unesp.br (M. Brienzo).
}

chemically joined by both non-covalent and covalent crossconnections [2]. Cellulose is the most important component of lignocellulose and has a crystalline structure. Hemicelluloses are a diverse class of polysaccharides with a structural function in lignocellulose. Lignin is a component that contributes to biomass recalcitrance, protecting cellulose fibres from microorganisms and enzymatic action. The complexity of these three components and their arrangement makes the vegetal cell wall naturally resistant and therefore making pretreatment necessary for its deconstruction, so that it becomes amenable to enzymatic hydrolysis. A pretreatment should modify the lignocellulosic material structure, exposing the polysaccharides to enzyme action [3].

Dilute acid is one among the leading pretreatment methods employed in the deconstruction of biomass. The target of this method is the solubilization of hemicelluloses leaving the pretreated material porous, enriched with cellulose and lignin and suitable for enzyme action [4]. During this process the molecular lignin bonds may also be broken followed by radical condensation and precipitation on the fibre surface [5]. The modification of lignin further allows for better enzyme action and catalytic adsorption to cellulose [6], thereby increasing cellulose accessibility [7]. Furthermore, hemicelluloses have some sugars with functional 
groups such as acetyl, which can hinder the action of both the hemicellulases [8] as well as cellulases enzymes [9]. The removal of these functional groups increases the hemicellulose accessibility to hemicellulases and consequently the exposure of the cellulose to cellulases.

Therefore, a low lignin content and a change in the substrate recalcitrance through cellulose exposure are key factors for biomass conversion to bioethanol [7]. In this context, this work is aimed at investigating the changes in the structural morphology, measured in cellulose accessibility, of different sugarcane bagasse samples in response to dilute acid pretreatment. Physicochemical properties such as the degree of polymerization of cellulose and the biomass crystallinity index were evaluated. Fourier transform infrared spectroscopy analysis (FTIR) and Principal component analysis (PCA) were used to identify structural differences or modification in the samples before and after alternative pretreatment conditions with different severities. The glucose yield from enzymatic hydrolysis was compared for the different pretreatment condition and modifications of the material properties.

\section{Materials and method}

\subsection{Raw materials and sample preparation}

Nineteen samples of bagasse from different varieties of sugarcane were supplied by the South African Sugarcane Research Institute (SASRI). The samples were milled using a laboratory ultracentrifugal mill model ZM200 basic (Resch GmbH, Germany). Prior to use, the milled samples were sieved in a vibratory sieve shaker model AS200 basic (Resch GmbH, Germany) and the particles retained between 425 and $825 \mu \mathrm{m}$ sieve porosity were packed in zipped plastic bags and stored in a temperature and moisture controlled room.

\subsection{Pretreatment}

The pretreatment of sugarcane bagasse samples was conducted according to Benjamin et al. (2013) [10]. According to this method, $1.5 \mathrm{~g}$ (dry weight) of sample material and $5 \mathrm{~mL}$ of a sulphuric acid solution of desired concentration was loaded into the reactor. The pretreatment was carried out at three different conditions, varied according to pretreatment severity i.e. low severity $\left(150{ }^{\circ} \mathrm{C}, 0.96 \%\right.$ $\mathrm{w} / \mathrm{w}$ for $15 \mathrm{~min})$, medium severity $\left(160{ }^{\circ} \mathrm{C}, 0.96 \% \mathrm{w} / \mathrm{w}, 15 \mathrm{~min}\right)$ and high severity $\left(180^{\circ} \mathrm{C}, 0.5 \% \mathrm{w} / \mathrm{w}\right.$ for $\left.15 \mathrm{~min}\right)$. The samples were also pretreated at $200{ }^{\circ} \mathrm{C}$ for $15 \mathrm{~min}$ without acid addition.

After the pretreatment, the pretreated slurry was washed with $500 \mathrm{~mL}$ of distilled water to separate the dissolved sugars from the water insoluble solids (WIS). The WIS was divided into two portions. One portion was used to study the effect of pretreatment on enzymatic hydrolysis and the other portion was used to investigate the change in physicochemical properties of the bagasse after pretreatment. The removal of components such as cellulose, hemicellulose and lignin was calculated considering their content $(\mathrm{g} / \mathrm{g})$ in the untreated and pretreated material. The initial biomass for the pretreatment is $1.5 \mathrm{~g}$, and after pretreatment a solid was recovered (WIS).

\subsection{Enzymatic hydrolysis}

Two hundred milligrams (200 mg dry weight) of untreated or control sample as well as each of the pretreated samples materials were transferred into $40 \mathrm{~mL}$ flasks containing a total volume of $10 \mathrm{~mL}$ solution containing $0.05 \mathrm{M}$ acetate buffer and an enzyme cocktail. The samples were placed in a shaking waterbath set at $50{ }^{\circ} \mathrm{C}$, at $120 \mathrm{rpm}$ mixing speed for $60 \mathrm{~min}$ to allow for adequate mixing to occur. The cellulase enzyme (Spezyme CP, GenencorDanisco, Denmark) was added at a loading rate of $15 \mathrm{FPU} / \mathrm{g}$ substrate. The cellulase was supplemented by adding $15 \mathrm{IU} / \mathrm{g}$ substrate of $\beta$-glucosidase (Novozym 188 -Novozymes A/S, Denmark). The reaction was stopped after $72 \mathrm{~h}$ of hydrolysis of the samples. The supernatant solution was collected and prepared for sugar analysis using high performance liquid chromatography (HPLC) as described below. The enzymatic hydrolysis assays were performed in duplicate and average results were reported. The glucan conversion was calculated according to Eq. (1):

$\begin{aligned} \text { Glucan conversion }(\%)= & \frac{[\text { Glucose }]+1.053[\text { Cellobiose }]}{1.111 \mathrm{f}[\text { Biomass }]} \\ & \times 100 \%\end{aligned}$

Where:

[Glucose] Glucose concentration (g/L) released during enzymatic hydrolysis

[Cellobiose] Cellobiose concentration $(\mathrm{g} / \mathrm{L})$ released during enzymatic hydrolysis

[Biomass] Dry biomass concentration at the beginning of the enzymatic hydrolysis $(\mathrm{g} / \mathrm{L})$

f Glucan fraction in dry biomass $(\mathrm{g} / \mathrm{g})$

1.053 Correction factor of cellobiose to equivalents of glucose.

1.111 Conversion factor of glucan to equivalents of glucose

\subsection{FT-ATR analysis}

Fourier-Transform Attenuated Total Reflectance (FT-ATR) spectroscopy was used to compare the changes in chemical characteristics between untreated and pretreated materials. Each sample was milled into a powder that passed through an 80 mesh screen. Each milled sample was analysed using a Perkin Elmer Spectrum GX. Five mg of sample material was pressed uniformly against a diamond surface using a spring-loaded anvil and analysed with a universal ATR accessory (Smart Performer from Thermo, equipped with ZnSe lenses). Infrared spectra were obtained with 32 scans in the range of $400 \mathrm{~cm}^{-1}$ to $4000 \mathrm{~cm}^{-1}$. The base line was corrected at $1800,1550,1200$ and $750 \mathrm{~cm}^{-1}$.

\subsection{Crystallinity index}

X-ray diffraction data was obtained using a PANalytical X'Pert Pro MPD with Bragg-Brenatno geometry, PreFix optics, with a $\mathrm{Cu}$ tube and an X'Celerator detector at an accelerating voltage of $40 \mathrm{kV}$ and a current of $30 \mathrm{~mA}$. The scans were done at a $2 \theta$ angle between $8^{\circ}$ and $28^{\circ}$ with a step of $0.05^{\circ}$ and a scan rate of $2^{\circ} / \mathrm{min}$. The crystallinity index $(\mathrm{CrI})$ was determined as the percentage of the crystalline material in biomass as shown in Eq (2):

$C r I=\frac{\left(I_{002}-I_{a m}\right)}{I_{002}} \times 100 \%$

Where: $\mathrm{CrI}=$ relative degree of crystallinity; $\mathrm{I}_{002}=$ intensity of the diffraction from the 002 plane at $2 \theta=22.5^{\circ} ; \mathrm{I}_{\mathrm{am}}=$ intensity of the background scatter at $2 \theta=18.7^{\circ}$

\subsection{Degree of polymerization}

Alpha-cellulose extraction and viscosity measurement of the extracted pulp using the standard TAPPI T230 test method was 
performed as reported elsewhere [11]. The $\alpha$-cellulose in the samples was determined by incubation of the $0.5 \mathrm{~g}$ of the solid in beakers containing $20 \mathrm{~mL}$ deionized water, $0.188 \mathrm{~g}$ sodium chlorite, and $63 \mu \mathrm{L}$ glacial acetic acid in a water bath at $70{ }^{\circ} \mathrm{C}$. Three more doses of sodium chlorite $(0.188 \mathrm{~g})$ and glacial acetic acid $(63 \mu \mathrm{L})$ were added after 2, 3 and $4 \mathrm{~h}$. The $\alpha$-cellulose viscosities were measured using the TAPPI test method where $0.125 \mathrm{~g} \alpha$-cellulose was placed in a test tube with $12.5 \mathrm{~mL}$ distilled water for $1 \mathrm{~h}$. Thereafter, $12.5 \mathrm{~mL}$ Cupriethylenediamine solution was added and stirred for $5 \mathrm{~min}$ and left for $2 \mathrm{~h}$ at room temperature until solubilization of glucan was complete. The soluble glucan pulp viscosity was measured using a Brookfield viscometer with $0.5 \%$ glucan solution, using $0.5 \mathrm{M}$ Cupriethylenediamine as a solvent. The pulp viscosity measurement was repeated three times and the average value was used. The pulp viscosity determined as centipoise (cp) was converted to degree of polymerization (DP) of polysaccharides according to Eq (3).

$\mathrm{DP}^{0.905}=0.75[954 \log (\mathrm{X})-325],(3)$

where $\mathrm{X}$ is the TAPPI viscosity in centipoises. The assays were performed in triplicate and average values were reported.

\subsection{Interior and exterior specific surface area}

Dye adsorption on the fibres was measured using a modified Simons' stain method [12]. $50 \mathrm{mg}$ (dry mass) of each pretreated sample was placed into a $15 \mathrm{~mL}$ centrifuge tube and $0.5 \mathrm{~mL}$ of a saline phosphate buffer solution ( $\mathrm{pH} 6,0.3 \mathrm{M} \mathrm{PO}_{4}, 1.4 \mathrm{mM} \mathrm{NaCl}$ ) was added. The Direct Orange (DO) solution $(10 \mathrm{mg} / \mathrm{mL})$ was also added at different volumes $(0.06,0.25,0.37,0.5,0.75,1.0 \mathrm{~mL})$. The Direct Blue (DB) solution $(10 \mathrm{mg} / \mathrm{mL})$ was then added to obtain a mixture of DO and DB dyes at a ratio of $1: 1$. The tubes were filled to a final volume of $5 \mathrm{~mL}$ with distilled water. The tubes were incubated at $70^{\circ} \mathrm{C}$ for $6 \mathrm{~h}$ at $120 \mathrm{rpm}$. After the incubation period, the tubes were centrifuged at $10,000 \mathrm{rpm}$ for $5 \mathrm{~min}$. The absorbance of the supernatant was measured using a spectrophotometer at a wavelength of 455 and $624 \mathrm{~nm}$. The concentration of the dye adsorbed onto the fiber was indirectly determined by calculating the difference between the initial and the final dye concentration in the supernatant. The concentrations of the DO and DB dyes were determined using Eqs (3) and (4), respectively.

$\mathrm{A}_{455 \mathrm{~nm}}=\mathrm{E}_{\mathrm{O} / 455} \mathrm{LC}_{\mathrm{O}}+\mathrm{E}_{\mathrm{B} / 455} \mathrm{LC}_{\mathrm{B}}$

$\mathrm{A}_{624 \mathrm{~nm}}=\mathrm{E}_{\mathrm{O} / 624} \mathrm{LC}_{\mathrm{O}}+\mathrm{E}_{\mathrm{B} / 624} \mathrm{LC}_{\mathrm{B}}$

Where $A_{455 n m}$ and $A_{624 n m}$ are the adsorption of the mixture at 455 and $624 \mathrm{~nm}$ respectively. $\mathrm{E}_{\mathrm{O} / 455}$ and $\mathrm{E}_{\mathrm{O} / 624}$ represent the extinction coefficients of each component at the respective wavelengths, and $\mathrm{L}$ is the path length (width of the cuvette $-1 \mathrm{~cm}$ ). The extinction coefficients of the dyes were calculated from the slopes of their standard absorbance calibration curves at 455 and $624 \mathrm{~nm}$. The values calculated and used in this study were: $\mathrm{E}_{\mathrm{O} / 455}=25.61 ; \mathrm{E}_{\mathrm{B} /}$ $455=0.86 ; \mathrm{E}_{\mathrm{O} / 624}=3.1 ;$ and $\mathrm{E}_{\mathrm{B} / 624}=16.45 \mathrm{~L} \mathrm{~g}^{-1} \mathrm{~cm}^{-1}$.

\subsection{Chemical composition of raw and pretreated materials}

Extractions with 95\% ethanol and then water were done according to the standard method to remove free sugars and extractives. The procedure described elsewhere was used for the determination the extractives content, ash and chemical composition of the extractive-free biomass samples [13]. The carbohydrate compositions of the respective samples were analysed via high performance liquid chromatography (HPLC) using an Aminex HPX-87H Ion Exclusion Column equipped with a Cation-H
Cartridge (Bio-Rad, Johannesburg, South Africa). The carbohydrate concentrations were measured via an RI detector (Shodex, RI-101) operated at $65{ }^{\circ} \mathrm{C}$ with a mobile phase of $5 \mathrm{mM}$ sulphuric acid and a flow rate of $0.6 \mathrm{~mL} / \mathrm{min}$. All analytical determinations were performed in duplicate and average results are reported.

\section{Results and discussion}

\subsection{Chemical composition of the bagasse samples prior and after pretreatment}

The chemical composition varied significantly between the samples as shown in Table 1. In general, the percentage of glucan, arabinoxylan, lignin, extractive and ash contents of the materials expressed on a dry weight basis ranged from 36.9 to $48.6 \%$, $24.6-32.8 \% 13.3-21.5 \%, 4.2-9.2 \%$ and $0.7-2.5 \%$, respectively. The values were however in the range of the typical bagasse samples reported in literature $[14,15]$. The structural carbohydrates content, specifically the sum of glucan and arabinan ranged between $64.0 \%$ and $79.2 \%$. The samples with reduced lignin content had generally a high structural carbohydrate content as well as low ash content, except for sample 10 . The observed difference could be attributed to the outcome of the breeding process used during crop development. The samples that showed a reduced lignin content were obtained from precision breeding varieties while those with high lignin were obtained from classical breeding varieties as reported previously [10]. The precision breeding varieties were developed by engineering the cell wall through down-regulating the expression of an endogenous enzyme UDP glucose dehydrogenase to increase sucrose content [16]. The reduction of lignin and ash content are the crucial steps toward the reduction of the recalcitrant of biomass for bioethanol production (my reference evaluation of bagasse).

The pretreated materials showed higher proportionally glucan and lignin content than untreated materials (Tables 1 and 2), due to the removal of hemicelluloses (arabinoxylan and acetyl group) [5]. The removal of arabinoxylan was increased with an increase in pretreatment severity (88.1-97.6\%). However, the removal of arabinoxylan in the biomass was slightly lower when no acid was used

Table 1

Chemical composition of untreated varieties sugarcane bagasse.

\begin{tabular}{llllll}
\hline \multirow{2}{*}{ Sample } & \multicolumn{2}{l}{ Untreated material \% $(\mathrm{g})^{*}$} & \multirow{2}{*}{ Ash } & \multirow{2}{*}{ Extractives } \\
\cline { 2 - 5 } & Glucan & Arabinoxylan & Lignin & & \\
\hline 1 & $44.30(0.66)$ & $24.97(0.37)$ & $16.40(0.25)$ & $1.46(0.02)$ & $8.87(0.13)$ \\
2 & $40.36(0.61)$ & $26.31(0.39)$ & $18.91(0.28)$ & $1.60(0.02)$ & $6.39(0.10)$ \\
$3^{(-)}$ & $44.06(0.66)$ & $24.57(0.37)$ & $14.93(0.22)$ & $1.57(0.02)$ & $7.32(0.11)$ \\
4 & $42.23(0.63)$ & $27.55(0.41)$ & $16.88(0.25)$ & $1.78(0.03)$ & $4.56(0.07)$ \\
5 & $41.60(0.62)$ & $28.44(0.43)$ & $18.30(0.27)$ & $1.53(0.02)$ & $6.71(0.10)$ \\
$6^{(+)}$ & $40.50(0.61)$ & $27.89(0.42)$ & $19.71(0.30)$ & $1.40(0.02)$ & $6.11(0.09)$ \\
7 & $41.13(0.62)$ & $26.98(0.40)$ & $18.95(0.28)$ & $1.69(0.03)$ & $7.29(0.11)$ \\
$8^{(+)}$ & $42.74(0.64)$ & $28.19(0.42)$ & $19.52(0.29)$ & $1.56(0.02)$ & $6.88(0.10)$ \\
9 & $42.98(0.64)$ & $32.76(0.49)$ & $17.43(0.26)$ & $2.50(0.04)$ & $4.21(0.06)$ \\
10 & $42.45(0.64)$ & $27.12(0.41)$ & $16.80(0.25)$ & $2.37(0.04)$ & $7.54(0.11)$ \\
$11^{(+)}$ & $48.60(0.73)$ & $30.62(0.46)$ & $21.48(0.32)$ & $1.04(0.02)$ & $5.51(0.08)$ \\
$12^{(+)}$ & $41.23(0.62)$ & $26.31(0.39)$ & $19.80(0.30)$ & $2.05(0.03)$ & $8.81(0.13)$ \\
13 & $42.75(0.64)$ & $25.34(0.38)$ & $17.37(0.26)$ & $1.90(0.03)$ & $9.22(0.14)$ \\
$14^{(-)}$ & $43.97(0.66)$ & $29.12(0.44)$ & $13.31(0.20)$ & $0.80(0.01)$ & $7.45(0.11)$ \\
15 & $40.19(0.60)$ & $28.23(0.42)$ & $15.88(0.24)$ & $0.94(0.01)$ & $8.06(0.12)$ \\
16 & $36.90(0.55)$ & $27.07(0.41)$ & $16.74(0.25)$ & $0.95(0.01)$ & $7.26(0.11)$ \\
$17^{(-)}$ & $42.85(0.64)$ & $29.74(0.45)$ & $15.59(0.23)$ & $0.92(0.01)$ & $7.96(0.12)$ \\
18 & $41.95(0.63)$ & $29.97(0.45)$ & $16.31(0.24)$ & $0.68(0.01)$ & $7.80(0.12)$ \\
$19^{(-)}$ & $40.68(0.61)$ & $29.93(0.45)$ & $15.31(0.23)$ & $0.87(0.01)$ & $6.12(0.09)$ \\
\hline Average & $42.18(0.63)$ & $27.95(0.42)$ & $17.34(0.26)$ & $1.45(0.02)$ & $7.06(0.11)$ \\
\hline
\end{tabular}

$(-)$ : sample with low lignin content; $(+)$ : sample with high lignin content; $\left({ }^{*}\right)$ Numbers in bracket represents the component mass in gram present in the material; Standard deviation lower than $5 \%$. 
Table 2

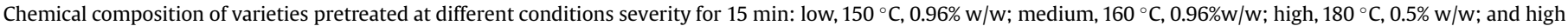
$200{ }^{\circ} \mathrm{C}$, no acid).

\begin{tabular}{|c|c|c|c|c|c|c|c|c|c|c|c|c|}
\hline \multirow[t]{3}{*}{ Sample } & \multicolumn{12}{|c|}{ Pretreated, composition base dry material $\%(\mathrm{~g})^{*}$} \\
\hline & \multicolumn{3}{|c|}{ Low severity } & \multicolumn{3}{|c|}{ Medium severity } & \multicolumn{3}{|c|}{ High severity } & \multicolumn{3}{|c|}{ High severity no-acid } \\
\hline & Glucan & Arabinoxylan & Lignin & Glucan & Arabinoxylan & Lignin & Glucan & Arabinoxylan & Lignin & Glucan & Arabinoxylan & Lignin \\
\hline 1 & $\begin{array}{l}67.32 \\
(0.64)\end{array}$ & $4.27(0.04)$ & $\begin{array}{l}23.17 \\
(0.22)\end{array}$ & $\begin{array}{l}69.77 \\
(0.62)\end{array}$ & $1.54(0.01)$ & $\begin{array}{l}25.17 \\
(0.22)\end{array}$ & $\begin{array}{l}68.59 \\
(0.61)\end{array}$ & $1.68(0.01)$ & $\begin{array}{l}28.17 \\
(0.25)\end{array}$ & $\begin{array}{l}67.25 \\
(0.61)\end{array}$ & $3.88(0.04)$ & $\begin{array}{l}27.17 \\
(0.25)\end{array}$ \\
\hline 2 & $\begin{array}{l}63.14 \\
(0.60)\end{array}$ & $4.53(0.04)$ & $\begin{array}{l}26.02 \\
(0.25)\end{array}$ & $\begin{array}{l}67.13 \\
(0.58)\end{array}$ & $1.76(0.02)$ & $\begin{array}{l}28.02 \\
(0.24)\end{array}$ & $\begin{array}{l}66.21 \\
(0.57)\end{array}$ & $1.07(0.01)$ & $\begin{array}{l}31.02 \\
(0.27)\end{array}$ & $\begin{array}{l}65.25 \\
(0.57)\end{array}$ & $3.13(0.03)$ & $\begin{array}{l}30.02 \\
(0.26)\end{array}$ \\
\hline $3^{(-)}$ & $\begin{array}{l}67.76 \\
(0.66)\end{array}$ & $4.20(0.04)$ & $\begin{array}{l}22.77 \\
(0.22)\end{array}$ & $\begin{array}{l}69.45 \\
(0.64)\end{array}$ & $1.16(0.01)$ & $\begin{array}{l}24.77 \\
(0.23)\end{array}$ & $\begin{array}{l}70.65 \\
(0.63)\end{array}$ & $1.19(0.01)$ & $\begin{array}{l}27.77 \\
(0.25)\end{array}$ & $\begin{array}{l}68.11 \\
(0.63)\end{array}$ & $3.53(0.03)$ & $\begin{array}{l}26.77 \\
(0.25)\end{array}$ \\
\hline 4 & $\begin{array}{l}67.05 \\
(0.63)\end{array}$ & $4.85(0.05)$ & $\begin{array}{l}24.69 \\
(0.23)\end{array}$ & $\begin{array}{l}67.53 \\
(0.60)\end{array}$ & $1.57(0.01)$ & $\begin{array}{l}26.69 \\
(0.24)\end{array}$ & $\begin{array}{l}67.39 \\
(0.59)\end{array}$ & $1.52(0.01)$ & $\begin{array}{l}29.69 \\
(0.26)\end{array}$ & $\begin{array}{l}65.50 \\
(0.59)\end{array}$ & $3.58(0.03)$ & $\begin{array}{l}28.69 \\
(0.26)\end{array}$ \\
\hline 5 & $\begin{array}{l}63.64 \\
(0.59)\end{array}$ & $5.20(0.05)$ & $\begin{array}{l}25.09 \\
(0.23)\end{array}$ & $\begin{array}{l}66.28 \\
(0.56)\end{array}$ & $1.69(0.01)$ & $\begin{array}{l}27.09 \\
(0.23)\end{array}$ & $\begin{array}{l}66.52 \\
(0.55)\end{array}$ & $1.32(0.01)$ & $\begin{array}{l}30.09 \\
(0.25)\end{array}$ & $\begin{array}{l}64.91 \\
(0.55)\end{array}$ & $3.78(0.03)$ & $\begin{array}{l}29.09 \\
(0.25)\end{array}$ \\
\hline $6^{(+)}$ & $\begin{array}{l}61.03 \\
(0.57)\end{array}$ & $5.28(0.05)$ & $\begin{array}{l}27.60 \\
(0.26)\end{array}$ & $\begin{array}{l}62.32 \\
(0.54)\end{array}$ & $1.68(0.01)$ & $\begin{array}{l}29.60 \\
(0.26)\end{array}$ & $\begin{array}{l}63.00 \\
(0.53)\end{array}$ & $1.39(0.01)$ & $\begin{array}{l}32.60 \\
(0.28)\end{array}$ & $\begin{array}{l}61.59 \\
(0.53)\end{array}$ & $3.80(0.03)$ & $\begin{array}{l}31.60 \\
(0.27)\end{array}$ \\
\hline 7 & $\begin{array}{l}64.07 \\
(0.60)\end{array}$ & $4.90(0.05)$ & $\begin{array}{l}25.69 \\
(0.24)\end{array}$ & $\begin{array}{l}65.60 \\
(0.58)\end{array}$ & $1.75(0.02)$ & $\begin{array}{l}27.69 \\
(0.24)\end{array}$ & $\begin{array}{l}64.98 \\
(0.57)\end{array}$ & $1.54(0.01)$ & $\begin{array}{l}30.69 \\
(0.27)\end{array}$ & $\begin{array}{l}61.60 \\
(0.57)\end{array}$ & $3.90(0.04)$ & $\begin{array}{l}29.69 \\
(0.27)\end{array}$ \\
\hline $8^{(+)}$ & $\begin{array}{l}60.90 \\
(0.54)\end{array}$ & $5.84(0.05)$ & $\begin{array}{l}25.94 \\
(0.23)\end{array}$ & $\begin{array}{l}61.18 \\
(0.52)\end{array}$ & $1.82(0.01)$ & $\begin{array}{l}30.94 \\
(0.26)\end{array}$ & $\begin{array}{l}62.95 \\
(0.51)\end{array}$ & $2.35(0.02)$ & $\begin{array}{l}30.94 \\
(0.25)\end{array}$ & $\begin{array}{l}60.23 \\
(0.51)\end{array}$ & $4.35(0.04)$ & $\begin{array}{l}31.94 \\
(0.27)\end{array}$ \\
\hline 9 & $\begin{array}{l}65.85 \\
(0.62)\end{array}$ & $5.54(0.05)$ & $\begin{array}{l}22.41 \\
(0.21)\end{array}$ & $\begin{array}{l}69.28 \\
(0.60)\end{array}$ & $1.69(0.01)$ & $\begin{array}{l}24.41 \\
(0.21)\end{array}$ & $\begin{array}{l}68.11 \\
(0.59)\end{array}$ & $1.20(0.01)$ & $\begin{array}{l}27.41 \\
(0.24)\end{array}$ & $\begin{array}{l}65.46 \\
(0.59)\end{array}$ & $3.72(0.03)$ & $\begin{array}{l}26.41 \\
(0.24)\end{array}$ \\
\hline 10 & $\begin{array}{l}65.92 \\
(0.59)\end{array}$ & $4.65(0.04)$ & $\begin{array}{l}24.66 \\
(0.22)\end{array}$ & $\begin{array}{l}63.09 \\
(0.56)\end{array}$ & $1.64(0.01)$ & $\begin{array}{l}27.66 \\
(0.25)\end{array}$ & $\begin{array}{l}66.69 \\
(0.55)\end{array}$ & $1.32(0.01)$ & $\begin{array}{l}29.66 \\
(0.25)\end{array}$ & $\begin{array}{l}65.03 \\
(0.53)\end{array}$ & $3.54(0.03)$ & $\begin{array}{l}28.66 \\
(0.23)\end{array}$ \\
\hline $11^{(+)}$ & $\begin{array}{l}65.39 \\
(0.60)\end{array}$ & $5.54(0.05)$ & $\begin{array}{l}24.81 \\
(0.23)\end{array}$ & $\begin{array}{l}67.48 \\
(0.58)\end{array}$ & $1.48(0.01)$ & $\begin{array}{l}26.81 \\
(0.23)\end{array}$ & $\begin{array}{l}66.72 \\
(0.57)\end{array}$ & $1.42(0.01)$ & $\begin{array}{l}29.81 \\
(0.25)\end{array}$ & $\begin{array}{l}64.78 \\
(0.57)\end{array}$ & $3.88(0.03)$ & $\begin{array}{l}28.81 \\
(0.25)\end{array}$ \\
\hline $12^{(+)}$ & $\begin{array}{l}62.59 \\
(0.59)\end{array}$ & $5.60(0.05)$ & $\begin{array}{l}25.50 \\
(0.24)\end{array}$ & $\begin{array}{l}67.44 \\
(0.57)\end{array}$ & $1.60(0.01)$ & $\begin{array}{l}27.50 \\
(0.23)\end{array}$ & $\begin{array}{l}66.70 \\
(0.56)\end{array}$ & $1.36(0.01)$ & $\begin{array}{l}30.50 \\
(0.26)\end{array}$ & $\begin{array}{l}65.51 \\
(0.57)\end{array}$ & $3.02(0.03)$ & $\begin{array}{l}29.50 \\
(0.25)\end{array}$ \\
\hline 13 & $\begin{array}{l}57.28 \\
(0.53)\end{array}$ & $6.35(0.06)$ & $\begin{array}{l}26.63 \\
(0.25)\end{array}$ & $\begin{array}{l}60.47 \\
(0.51)\end{array}$ & $1.64(0.01)$ & $\begin{array}{l}31.63 \\
(0.27)\end{array}$ & $\begin{array}{l}63.53 \\
(0.50)\end{array}$ & $1.67(0.01)$ & $\begin{array}{l}31.63 \\
(0.25)\end{array}$ & $\begin{array}{l}59.71 \\
(0.46)\end{array}$ & $4.17(0.03)$ & $\begin{array}{l}33.63 \\
(0.26)\end{array}$ \\
\hline $14^{(-)}$ & $\begin{array}{l}69.83 \\
(0.66)\end{array}$ & $5.69(0.05)$ & $\begin{array}{l}19.38 \\
(0.18)\end{array}$ & $\begin{array}{l}71.74 \\
(0.64)\end{array}$ & $1.45(0.01)$ & $\begin{array}{l}21.38 \\
(0.19)\end{array}$ & $\begin{array}{l}71.63 \\
(0.63)\end{array}$ & $1.57(0.01)$ & $\begin{array}{l}24.38 \\
(0.21)\end{array}$ & $\begin{array}{l}69.11 \\
(0.72)\end{array}$ & $4.90(0.05)$ & $\begin{array}{l}23.38 \\
(0.25)\end{array}$ \\
\hline 15 & $\begin{array}{l}63.96 \\
(0.59)\end{array}$ & $6.40(0.05)$ & $\begin{array}{l}23.43 \\
(0.21)\end{array}$ & $\begin{array}{l}67.97 \\
(0.56)\end{array}$ & $1.75(0.01)$ & $\begin{array}{l}25.43 \\
(0.21)\end{array}$ & $\begin{array}{l}66.56 \\
(0.55)\end{array}$ & $1.68(0.01)$ & $\begin{array}{l}28.43 \\
(0.24)\end{array}$ & $\begin{array}{l}68.43 \\
(0.55)\end{array}$ & $3.64(0.03)$ & $\begin{array}{l}27.43 \\
(0.22)\end{array}$ \\
\hline 16 & $\begin{array}{l}61.65 \\
(0.56)\end{array}$ & $5.60(0.04)$ & $\begin{array}{l}25.70 \\
(0.23)\end{array}$ & $\begin{array}{l}64.64 \\
(0.53)\end{array}$ & $1.64(0.01)$ & $\begin{array}{l}27.70 \\
(0.23)\end{array}$ & $\begin{array}{l}65.62 \\
(0.52)\end{array}$ & $1.80(0.01)$ & $\begin{array}{l}30.70 \\
(0.24)\end{array}$ & $\begin{array}{l}60.37 \\
(0.46)\end{array}$ & $3.96(0.03)$ & $\begin{array}{l}32.70 \\
(0.25)\end{array}$ \\
\hline $17^{(-)}$ & $\begin{array}{l}65.93 \\
(0.62)\end{array}$ & $4.44(0.04)$ & $\begin{array}{l}21.59 \\
(0.20)\end{array}$ & $\begin{array}{l}68.73 \\
(0.60)\end{array}$ & $1.97(0.02)$ & $\begin{array}{l}23.59 \\
(0.20)\end{array}$ & $\begin{array}{l}68.98 \\
(0.59)\end{array}$ & $2.09(0.02)$ & $\begin{array}{l}26.59 \\
(0.23)\end{array}$ & $\begin{array}{l}67.39 \\
(0.65)\end{array}$ & $5.05(0.05)$ & $\begin{array}{l}25.59 \\
(0.25)\end{array}$ \\
\hline 18 & $\begin{array}{l}64.82 \\
(0.56)\end{array}$ & $4.44(0.04)$ & $\begin{array}{l}23.95 \\
(0.21)\end{array}$ & $\begin{array}{l}66.80 \\
(0.54)\end{array}$ & $1.89(0.02)$ & $\begin{array}{l}25.95 \\
(0.21)\end{array}$ & $\begin{array}{l}65.25 \\
(0.52)\end{array}$ & $1.84(0.01)$ & $\begin{array}{l}28.95 \\
(0.23)\end{array}$ & $\begin{array}{l}61.96 \\
(0.48)\end{array}$ & $5.85(0.05)$ & $\begin{array}{l}29.95 \\
(0.23)\end{array}$ \\
\hline $19^{(-)}$ & $\begin{array}{l}69.11 \\
(0.62)\end{array}$ & $4.01(0.04)$ & $\begin{array}{l}21.13 \\
(0.19)\end{array}$ & $\begin{array}{l}68.29 \\
(0.60)\end{array}$ & $1.41(0.01)$ & $\begin{array}{l}18.13 \\
(0.16)\end{array}$ & $\begin{array}{l}68.60 \\
(0.59)\end{array}$ & $1.46(0.01)$ & $\begin{array}{l}26.13 \\
(0.23)\end{array}$ & $\begin{array}{l}67.30 \\
(0.61)\end{array}$ & $3.96(0.04)$ & $\begin{array}{l}25.13 \\
(0.23)\end{array}$ \\
\hline Average & $\begin{array}{l}64.59 \\
(0.60)\end{array}$ & $5.12(0.30)$ & $\begin{array}{l}24.22 \\
(0.22)\end{array}$ & $\begin{array}{l}66.59 \\
(0.58)\end{array}$ & $1.64(0.01)$ & $\begin{array}{l}26.32 \\
(0.23)\end{array}$ & $\begin{array}{l}66.77 \\
(0.56)\end{array}$ & $1.55(0.01)$ & $\begin{array}{l}29.22 \\
(0.25)\end{array}$ & $\begin{array}{l}64.71 \\
(0.57)\end{array}$ & $3.98(0.03)$ & $\begin{array}{l}28.75 \\
(0.25)\end{array}$ \\
\hline Glucan removal (\%) & 4.76 & & & 7.94 & & & 11.11 & & & 9.52 & & \\
\hline $\begin{array}{l}\text { Hemicellulose } \\
\text { removal (\%) }\end{array}$ & & 88.10 & & & 97.62 & & & 97.62 & & & 92.86 & \\
\hline Lignin removal (\%) & & & 15.38 & & & 11.54 & & & 3.85 & & & 3.85 \\
\hline
\end{tabular}

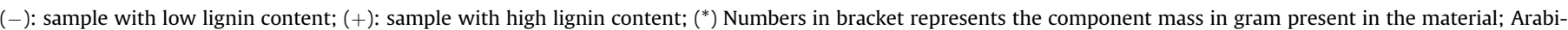
noxylan and other components removal was calculated based on the initial and final mass (WIS), and their respective percentage; standard deviation lower than $5 \%$.

compared to dilute acid pretreated material. Uncatalysed pretreatment largely depends on the acetic acid released during cleavage of acetyl group. The infiltration of hot water into the fibers causes solubilization of xylan, cleavage of acetyl group to produce acetic acid [17]. The organic acids generated act as catalysts which accelerate the auto-hydrolysis reaction. The pretreated material generated through this method has a lower inhibitive effect. However, most of the sugars hydrolyzed during pretreatment remain in oligomeric form and therefore, cannot be directly fermented. Consequently, a post hydrolysis step is usually required prior to fermentation $[18,19]$, which could possibly increase the production cost.

\subsection{FT-IR analysis of untreated materials}

The FT-IR spectra of untreated materials are shown in Fig. $1 \mathrm{~A}$ and were typical of the structure of sugarcane bagasse [7]. Principal component analysis (PCA) was applied to the FT-IR spectral data to allow for the discrimination of samples based on spectral information, and the identification of groups of samples that bear similarities or differences [20]. The PCA score plot depicts that samples were separated mainly on PC1 axis (Fig. 2A). This axis contained most of the spectral information (63.3\%) compared to PC2 (13.3\%). The samples were widely dispersed on the PC1 axis without group identification, indicating that the samples were different. This result is in agreement with the chemical composition of the materials (Table 1). Furthermore, the load plot for principle components showed several discrepancies (Fig. 2B). The main differences were observed in $900,1200,1370,1510$ and $1550 \mathrm{~cm}^{-1}$ the regions, which are related to $\mathrm{C}-\mathrm{O}-\mathrm{C}$ of glycosidic linkage, $\mathrm{C}-\mathrm{O}$ and $\mathrm{C}-\mathrm{H}$ in polysaccharides and lignin, $\mathrm{O}-\mathrm{H}$ phenolic compounds, $\mathrm{C}=\mathrm{C}$ in lignin and $\mathrm{C}-\mathrm{O}$ in aromatic ring, respectively.

\subsection{FT-IR analysis of pretreated materials}

The FT-IR spectra of untreated and pretreated materials were 


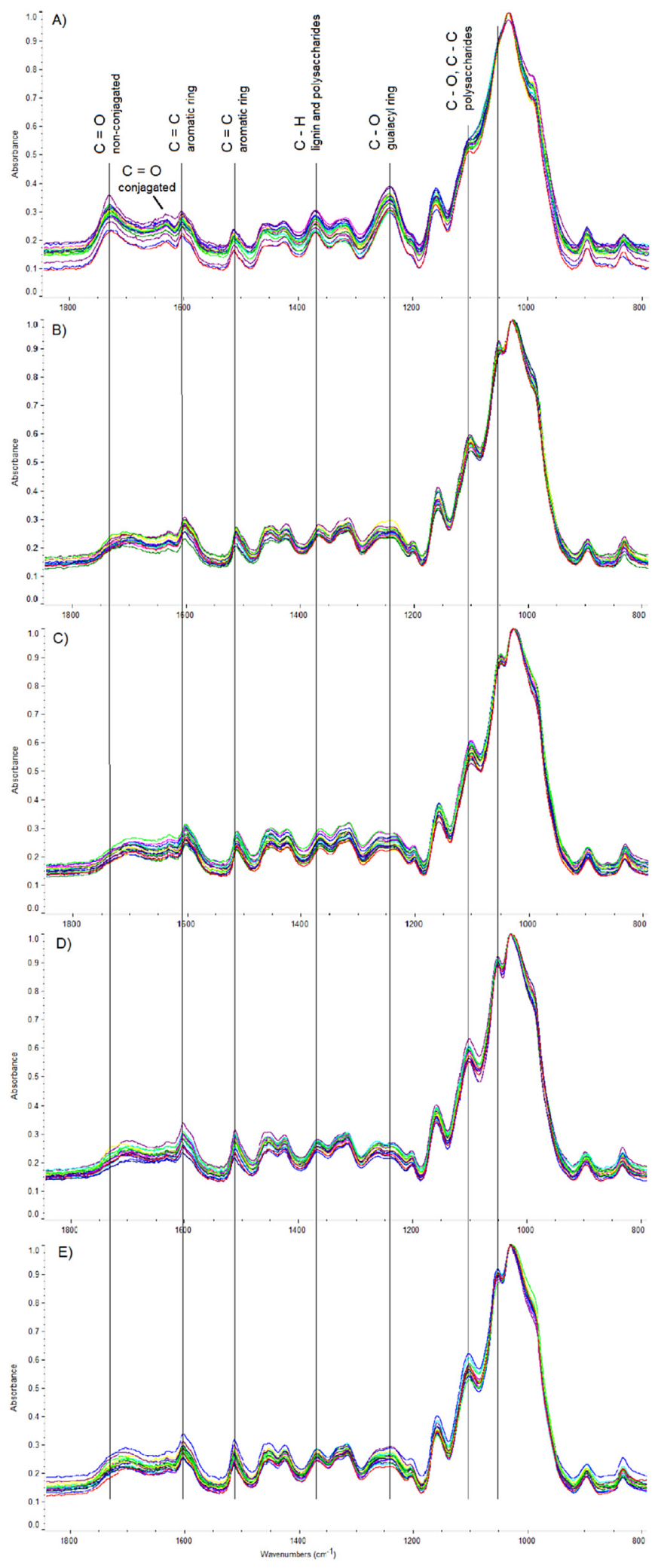

Fig. 1. FT-ATR spectra of untreated sugarcane bagasse varieties (A) and pretreated at different conditions severity for $15 \mathrm{~min}$ : low, $150{ }^{\circ} \mathrm{C}, 0.96 \% \mathrm{w} / \mathrm{w}(\mathrm{B})$; medium, $160{ }^{\circ} \mathrm{C}$ $0.96 \% \mathrm{w} / \mathrm{w}(\mathrm{C})$; high, $180{ }^{\circ} \mathrm{C}, 0.5 \% \mathrm{w} / \mathrm{w}(\mathrm{D})$; and high $200{ }^{\circ} \mathrm{C}$, no acid (E).

different (Fig. 1). The FT-IR spectra of the pretreated materials showed new bands at 1100 and $1050 \mathrm{~cm}^{-1}$, while in untreated material the spectrum showed a soft shoulder in this region. The acid pretreatment caused several modifications in the structure and the composition of the pretreated materials via the removal of hemicelluloses and alteration of the lignin structure (Table 2). This result was in agreement with the data reported elsewhere [5].

Furthermore, a new band appeared at 1100 and $1050 \mathrm{~cm}^{-1}$ (Fig. 1, severity: low (B), medium (C), high (D) and high with no acid (E)), while in the spectra of the untreated material it was a soft shoulder. The formation of this band is due to the deformation of $\mathrm{C}-\mathrm{O}$, which is related to glucose ring [21]. The enrichment of cellulose could probably be interfering with the intensity of this band. However, the band at $1730 \mathrm{~cm}^{-1}$ decreased due to the removal of arabinoxylan component (acetyl and uronic ester groups) after pretreatment $[15,20]$. Generally, the intensity of the bands between 1600 and 1300 increased with increasing pretreatment severity. Conversely, the intensities of the bands between 1200 and $1300 \mathrm{~cm}^{-1}$ were reduced compared to other bands. These bands represent $\mathrm{C}-\mathrm{OH}$ deformation and $\mathrm{C}-\mathrm{O}$ stretching of phenolics [22]. This was expected due to modification of lignin but its content was less affected (Table 2). This region is related to lignin, and modification in its content or structure by the pretreatment can change the band intensity. The band at $1240 \mathrm{~cm}^{-1}$ was ascribed to a $\mathrm{C}-\mathrm{O}$ of a guaiacyl ring. Thus, it can be used to evaluate lignin removal during delignification processes [21]. Similarly, a sharp band observed at $1510 \mathrm{~cm}^{-1}$ signifies a proportional increase in lignin concentration due to the removal of hemicelluloses in the biomass after pretreatment (Fig. 1).

The FT-IR spectrum bands provide evidence of structural modifications of the biomass after pretreatment. Glucan was removed in average values between 4.7, 7.9-11.1\% (based on residual mass) and lignin (3.8-15.3\%) depending on pretreatment severity. Most of modifications observed were related to the presence and nature of lignin and lignin-carbohydrate complexes (Fig. 1). Thus upon pretreatment, the lignin in the biomass became more hydrophilic due to increases in carbonyl and hydroxyl group contents as observed in the identified spectral bands (Fig. 1). The principal component analysis separated the samples into two groups based on the pretreatment conditions (Fig. 3A). The first group comprised samples treated at a moderate temperature $\left(150-180{ }^{\circ} \mathrm{C}\right)$ and the other group belongs to those treated at a high temperature $\left(200^{\circ} \mathrm{C}\right)$. The PCA score plot showed that pretreated samples were separated mainly on PC1 axis, which contained most of the spectral information of $62.7 \%$, while PC2 axis showed $26.4 \%$. The samples pretreated at high severity with no catalyst were discriminated in one group, while the samples pretreated at low, medium and high severity converged into a mixed group. The observed groups could be due to differences in chemical composition between the pretreated materials as revealed by the loading plot (Fig. 3B). The differences were related to wavenumbers in the spectral region between 1200 and $1600 \mathrm{~cm}^{-1}$ particularly at 1200, 1370 and $1510 \mathrm{~cm}^{-1}$. These wavenumbers could be attributed to $\mathrm{C}-\mathrm{O}$ and $\mathrm{C}-\mathrm{H}$ in polysaccharides and lignin, $\mathrm{O}-\mathrm{H}$ phenolic compounds and $\mathrm{C}=\mathrm{C}$ in lignin.

\subsection{Enzymatic hydrolysis yield}

Glucose yield after enzymatic hydrolysis varied significantly among the samples (Fig. 4). The observed differences could be attributed to the varied chemical composition between the samples. The three samples with low glucose yield (samples 5, 11 and 12) also had high lignin and ash contents (Table 1). The exception was on sample 9, which despite having an intermediate lignin content (17.4\%), exhibited the lowest levels of glucose yield (30.8-54.3\%) at all instances. However, this sample (sample 9) showed the highest ash content (Table 1). The highest glucose 

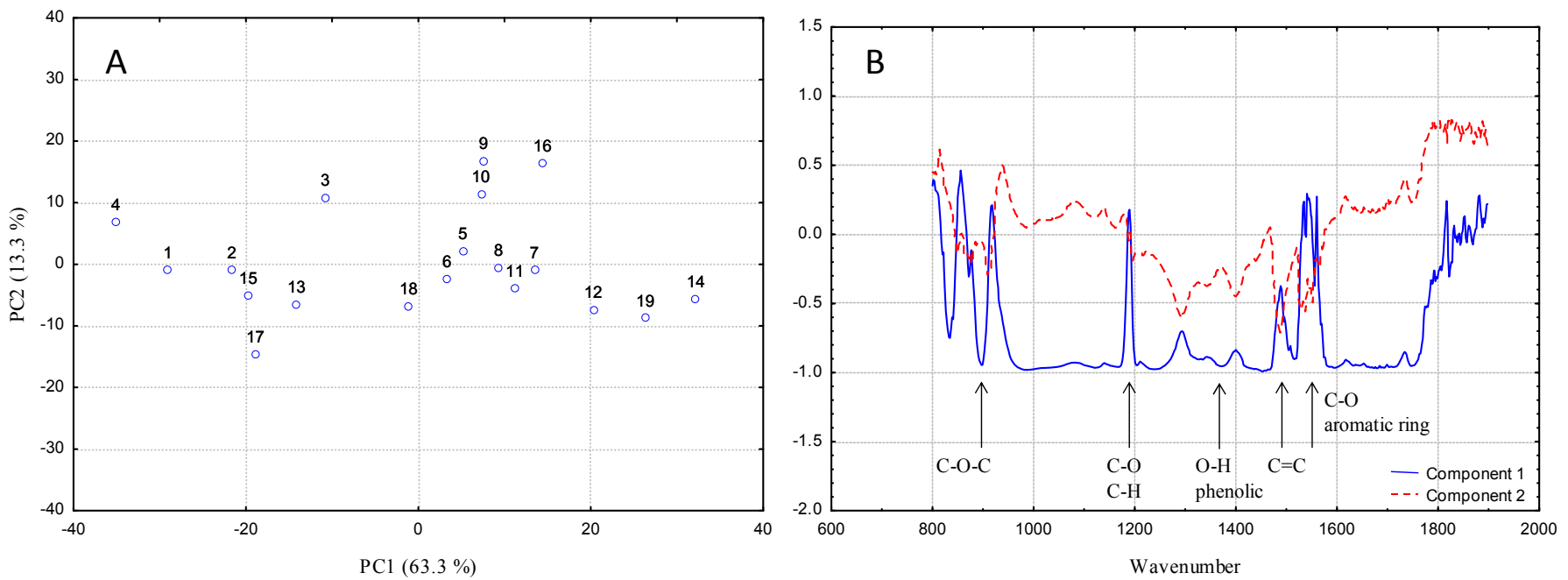

Fig. 2. Score plots of FT-ATR of different samples of untreated sugarcane bagasse (A). Load plot for a data matrix containing FT-ATR spectra (B).
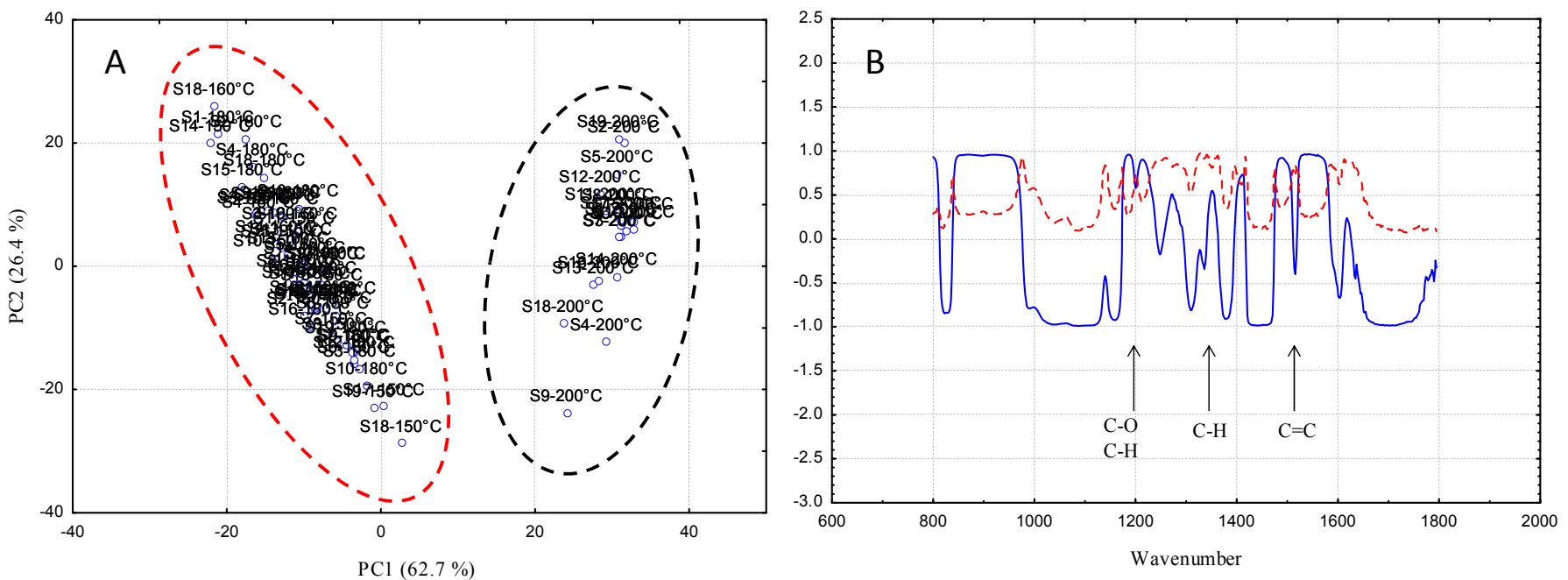

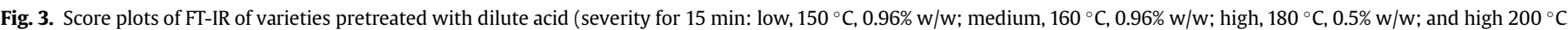
no acid) (A). Loads plot for a date matrix containing FT-IR spectra (B).

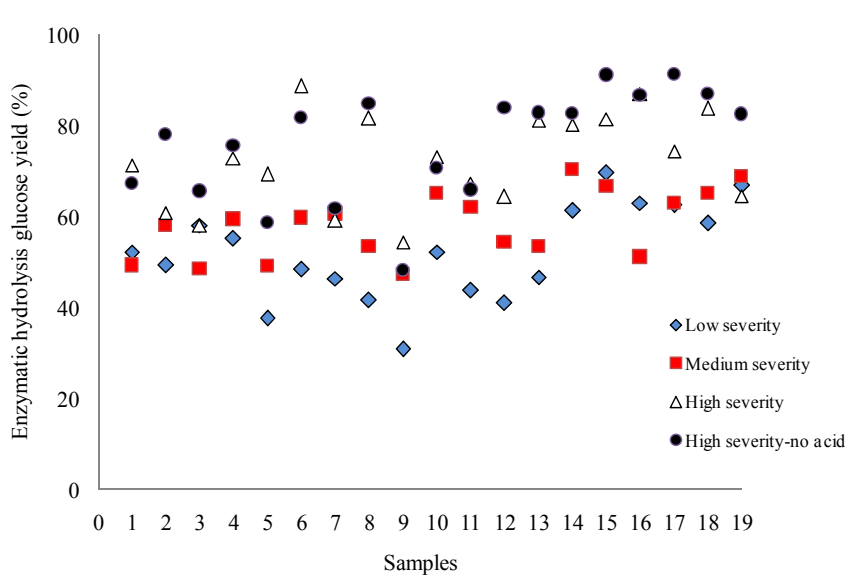

Fig. 4. Profile of enzymatic hydrolysis of different condition dilute acid pretreated (severity for $15 \mathrm{~min}$ : low, $150{ }^{\circ} \mathrm{C}, 0.96 \% \mathrm{w} / \mathrm{w}$; medium, $160{ }^{\circ} \mathrm{C}, 0.96 \% \mathrm{w} / \mathrm{w}$; high, $180{ }^{\circ} \mathrm{C}$ $0.5 \% \mathrm{w} / \mathrm{w}$; and high $200^{\circ} \mathrm{C}$, no acid) varieties with $15 \mathrm{FPU} / \mathrm{g}$, supplemented by $15 \mathrm{U} / \mathrm{g}$ of $\beta$-glucosidase. yield in the samples was a function of the severity of the pretreatment. Further, high glucose yields were generally observed on the samples with low lignin as well as low ash contents. The lignin matrix can impose various structural barriers on the cellulase and prevent effective binding of the enzymes thereof, leading to low cellulose digestibility [23]. Other factors that contribute to the recalcitrance of the biomass include lignin distribution, type of cell and composition [24,25]. On the other hand, ash has been proven to have negative effect on the cellulose digestibility due to its neutralization capacity when dilute acid pretreatment is used [10].

Furthermore, the increase in the pretreatment severity could not eliminate the difference in glucose yields between the samples (Fig. 1). Three groups could be distinguished based the pretreatment severity (at low severity (30.8 - to 69.5\%), at medium severity $(47.3 \%-70.3 \%)$ and at high severity (54.2-88.5\%)). This means that the digestibilities of the materials were largely determined by the chemical composition of the material (Tables 1 and 2). This finding is in agreement with the previous studies on the evaluation of cellulose digestibly of pretreated materials $[10,26]$. 


\subsection{Accessible surface area}

The enzyme accessibility as measured through the specific interior and exterior surface areas of the pretreated materials was correlated to glucose yield using the Simons' staining technique. The method is based on the measure of the adsorption of Direct Orange (exterior surface area) and Direct Blue (interior surface area) dyes on biomass materials [27]. According to this method, the total dye adsorption is determined as the sum of the adsorption of Direct Blue and Orange dyes. The total dye adsorption represents the sum of internal and external surface areas as determined by the adsorption of Direct Blue and Orange dyes, respectively. The results showed that glucose yield was linearly correlated with total dye adsorption $\left(\mathrm{R}^{2}=0.9049\right)$ (Fig. 5A). The dye adsorption onto the lignocellulosic fibre is an indication of the material's available physical contact surface area for enzyme action [28]. The removal of arabinoxylan combined with lignin modification increases the exposed specific surface area of the cellulose for enzymatic hydrolysis (Table 2, Fig. 1). The acid pretreatment removed arabinoxylan resulting in a proportional increase in the lignin content of the samples (Fig. 1), which in turn reallocated on the fibre surface [29].

The glucose yield also showed a linear relationship with the available external surface area (measured by Direct Orange dye) as depicted in Fig. 5B $\left(\mathrm{R}^{2}=0.9064\right)$. However, a weak correlation coefficient $\left(\mathrm{R}^{2}=0.7168\right)$ was obtained between internal specific surface area (measured by Blue dye) and the glucose yield (Fig. 5C). The Direct Orange dye has larger molecules with a high affinity for cellulose and easily adsorbs to the external surface of the exposed cellulose fibre. The Direct Blue dye on the other hand has smaller molecules which easily penetrate into the porous structure of the fibres without adsorbing onto the cellulose [27]. The affinity of the dyes to material components was determined and it was found that the amount of Blue dye adsorbed was not correlated with cellulose content. Furthermore, the amount of Blue and Orange dye adsorbed did not correlate with lignin content (data not shown). The direct comparison of adsorbed dye in relation to the chemical composition of the material showed that the method was not influenced by the components of the material. The method is based on the application of 6 different dyes concentrations in an increasing sequence until dyes adsorption stabilizes with no further adsorption. Further, the maximum adsorption is based on the linearization of the data [30]. Accordingly, the calculated maximum adsorption is considered in the linear phase adsorption and not in the stabilized phase to avoid a multilayer type of adsorption. These characteristics bring more confidence and robustness in the analysis of lignocellulosic material to predict the enzymatic digestibility.

Apart from weak correlation shown between Blue dye and glucose yield, this measurement allows for the comparison between the available internal and external surfaces of the biomass materials. In general, biomass materials pretreated at different severities will generate WIS with variable enzyme accessibility based on the characteristics of their internal and external surface areas [31,32], or even by enzyme action [33]. The Blue dye molecules are small and probably penetrate into the pores where enzyme could not reach. This kind of behavior is observed also with techniques such as the BET analysis, which is applied in materials with small pores sizes. The determination of pores sizes using different dextran probes indicates that there is a huge diversity in the structure and sizes of pores in different material $[34,35]$. On the
A)

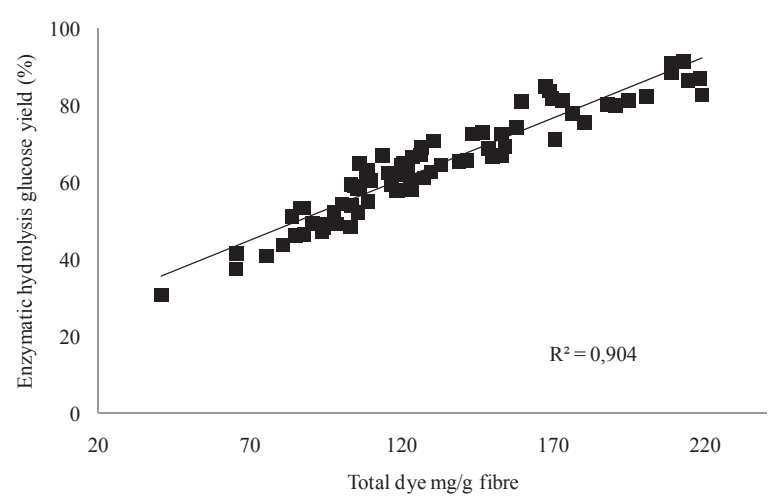

B)

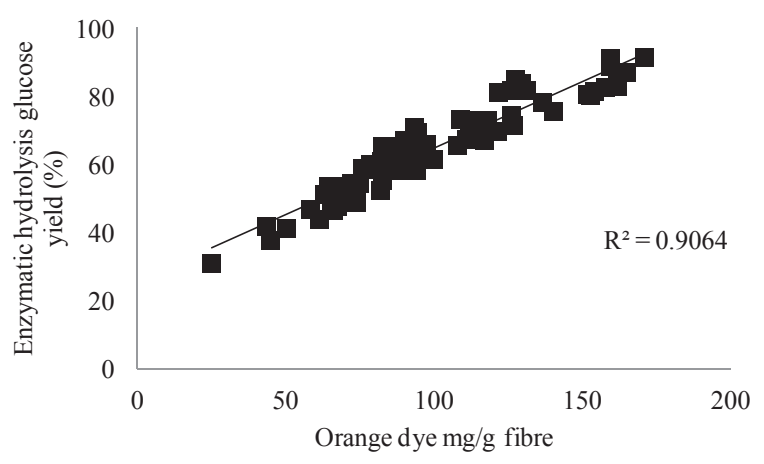

C)

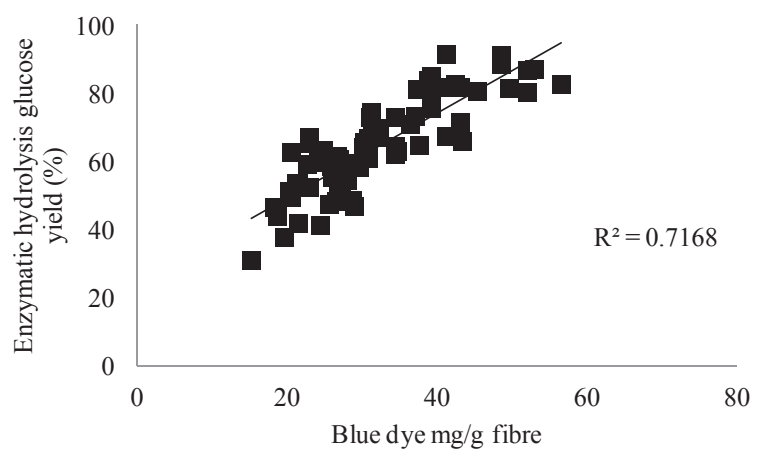

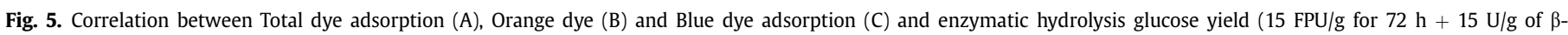
glucosidase) of the sugarcane bagasse varieties pretreated. 
other hand, the Simons' staining technique measures individually the internal and external specific surface area and these together can efficiently predict the glucose digestibility. The determination of the external surface areas is important for dilute acids pretreated biomass as this method results in lignin precipitation onto the fibre surface. As a consequence, its percentage content increases proportionally (Table 2). This behavior is typically observed for high severity pretreatment, concisely, at higher temperatures. The precipitated lignin on the fibre surface creates a barrier to enzymes access to the cellulose $[5,23]$. Further, lignin removal which promotes enzyme access to the cellulose was found to decrease with the increase in the pretreatment severity (Table 1).

The pretreatment of the samples at different conditions generated a large range of substrates with different chemical compositions, specific surface areas, and consequently different degrees of digestibility. The material with higher dye adsorption were observed at high pretreatment severity when no acid catalyst was used. The best enzymatic hydrolysis glucose yield was also obtained at these pretreatment conditions. These conditions were also directly responsible for arabinoxylan removal and lignin modification (Fig. 1), which in turn resulted in increases in the substrate accessibility by increasing the proportion of exposed pores and also the fragmentation of the fibres (Fig. 5). The comparison of different pretreatment conditions using dye adsorption is useful to determine the accessible cellulose to enzyme action [12], which also can be dependent of the cellulose content of the material [7].

The comparison of pretreated samples can lead to the identification of relations between biomass digestibility based on glucose yield and total dye adsorption. For instance, sample 3, 5, 7, 9 and 11 showed lower increments in glucose yield when the pretreatment severity was increased (Supplemental Table 1). The samples had a low content of total dye adsorbed; suggesting a poor response of the samples to pretreatment. Conversely, the best samples in terms of glucose yield such as sample 19 showed high glucose yield even at low severity. This sample also had a low initial lignin content (Tables 1 and 2). The same result was also observed for other samples with low lignin contents (3,14 and 17).

\subsection{Crystallinity index (CrI) of biomass and cellulose degree of polymerization $(D P)$}

The samples with different behavior to the enzymatic hydrolysis yield $(4,8,9,11,12,14,17,18$ and 19) were analysed for biomass crystallinity. A CrI higher than $40 \%$ was obtained in all samples, except for sample 4, (Table 3). As expected, the CrI was increased after the materials were pretreated and the increase was related to the increase in pretreatment severity [3]. Dilute acid pretreatment of the biomass removes the amorphous part of the biomass (mainly arabinoxylan) and leaves the pretreated material enriched with cellulose (Table 2). However, the differences in CrI between the samples did not correlate with the enzymatic hydrolysis yield. The most severe pretreatment conditions could attack cellulose component most likely the amorphous fraction, generating residual cellulose that is even more crystalline [7]. This residual cellulose could be more resistant to enzyme action due the crystallinity property resulting from high severity pretreatment.

Pretreated samples 11,14, 18 and 19 were then selected for the evaluation of the degree of polymerization (DP) and the obtained results are summarized in Table 3. The DP ranged from 553 to 818. The highest DP was observed on sample 19 and the lowest value was obtained from sample 14. The observed results were in agreement with the data reported on literature, indicating a common DP value below 1000 [36,37]. Acid pretreatment can break down of glycosidic bonds linking cellulose units, decreasing the length of the cellulose chain or specifically the number of monomeric glucose units comprising a cellulose chain. However, an increase in the process severity parameters did not result in extensive reduction of the DP of cellulose. Probably, a much higher acid concentration could contribute to DP decrease due to the splitting of glucose units from the cellulose chain which is a typical carbohydrate reaction under acidic conditions as mentioned above. When the final DP was plotted against enzymatic hydrolysis yield, no clear trend was observed. Moreover, literature has not shown any consensus on the effect of the DP on the hydrolysis of cellulose in the lignocellulosic materials. Furthermore, even for pure cellulose the DP effect has not been shown to influence the total sugar yield, but enzyme synergism has been shown to be more important in this regard [38]. The DP reduction is a desirable effect of the pretreatment process due to the increase in the content of individual cellulose ends which are exposed to the exoglucanase action. Similarly, a low DP cellulose chain could be hydrolyzed by enzymes with much ease due a lower degree of hydrogen bonding resulting into a much simpler supramolecular structure of the cellulose, compared to high DP cellulose [37]. In the present work, physicochemical properties have been shown to be the major contributor to the similarity in the glucose yield for samples 14 and 18 which are different varieties in terms of DP.

\subsection{Relationship between physicochemical properties and enzymatic hydrolysis}

This work investigated the relationship between the physicochemical and structural properties of the several samples of

Table 3

Crystallinity index (CrI) and degree of polymerization (DP) of the extreme varieties based on enzymatic hydrolysis glucose yield.

\begin{tabular}{|c|c|c|c|c|c|c|}
\hline & \multirow[t]{2}{*}{ Sample } & \multirow[t]{2}{*}{ Untreated } & \multicolumn{4}{|c|}{ Dilute acid pretreated } \\
\hline & & & Low severity & Medium severity & High severity & High severity no acid \\
\hline \multirow[t]{9}{*}{$\mathrm{CrI}(\%)$} & 4 & 33.64 & 57.72 & 56.02 & 58.74 & 56.78 \\
\hline & 8 & 44.20 & 56.24 & 59.92 & 60.45 & 58.83 \\
\hline & 9 & 41.98 & 56.82 & 59.15 & 58.55 & 55.54 \\
\hline & 11 & 48.95 & 55.26 & 59.95 & 60.16 & 61.85 \\
\hline & 12 & 46.54 & 57.36 & 58.55 & 57.27 & 55.23 \\
\hline & 14 & 49.64 & 55.28 & 59.05 & 60.77 & 61.00 \\
\hline & 17 & 49.79 & 62.24 & 62.01 & 64.54 & 62.34 \\
\hline & 18 & 49.62 & 61.38 & 61.31 & 62.29 & 63.26 \\
\hline & 19 & 46.66 & 59.29 & 60.00 & 60.84 & 67.96 \\
\hline \multirow[t]{4}{*}{ DP } & 11 & - & 702.30 & 687.14 & 687.14 & 716.75 \\
\hline & 14 & - & 617.80 & 619.73 & 562.69 & 553.28 \\
\hline & 18 & - & 791.69 & 778.08 & 768.66 & 762.63 \\
\hline & 19 & - & 818.27 & 802.60 & 813.13 & 768.66 \\
\hline
\end{tabular}


sugarcane bagasse and enzymatic hydrolysis yield after they have been subjected to optimized pretreatment conditions. The results indicated that some of the selected samples were suitable as raw materials in an optimized industrial production process $[10,19]$. The structural and morphological properties changed after pretreatment resulting in increased cellulose accessibility of sugarcane bagasse $[3,7]$. The results showed that sample with high enzymatic hydrolysis glucose yield also showed high accessibility (Fig. 5, Supplemental Table 1). Infrared analyses showed similar spectra for both non-acid and acid catalyzed pretreatment on the samples. Acid catalysis also reduced the acetyl content of the biomass samples through the solubilization of the arabinoxylan fraction [39]. However, the Principal Component Analysis (PCA) indicates that there are several structural differences between untreated and pretreated samples (Fig. 3B). Therefore, cellulose accessibility is one of the best analyses methods that can be used to predict enzymatic hydrolysis yield for sugarcane bagasse hydrothermal (acid or not added) pretreated in addition to chemical composition and physicochemical properties.

\section{Conclusion}

Several samples of sugarcane bagasse pretreated with dilute sulfuric acid were analysed to establish the relationship between pretreatment severity and lignin content, substrate accessibility and enzymatic digestibility. The specific surface area of the materials was altered after pretreatment, improving cellulose accessibility, which was confirmed by glucose yield after enzymatic hydrolysis. The specific internal and external surface areas (accessibility) of the pretreated samples were correlated with enzymatic digestibility. The results also showed that crystallinity increased with an increase in pretreatment severity while degree of polymerization was decreasing. High pretreatment severity contributes to lignin modification/reallocation and as a consequence, as the results suggest, improved the cellulose accessibility. Further, while physicochemical properties are important, measuring cellulose accessibility is also a very important tool as a means for predicting enzymatic digestibility of pretreated biomass.

\section{Acknowledgments}

Authors are thankful to South African Sugarcane Research Institute (SASRI) for financial support and providing sugarcane bagasse samples, as well as the National Research Foundation (NRF) through its Technology and Human Resources for Industry Program (THRIP) and Claude Leon Foundation Postdoctoral Fellowship.

\section{Appendix A. Supplementary data}

Supplementary data related to this article can be found at http:// dx.doi.org/10.1016/j.renene.2016.12.037.

\section{References}

[1] A. Limayem, S.C. Ricke, Lignocellulosic biomass for bioethanol production: current perspectives, potential issues and future prospects, Prog. Energy Combust. Sci. 38 (2012) 449-467.

[2] J. Pérez, J. Muñoz-Dorado, T. De la Rubia, J. Martinez, Biodegradation and biological treatments of cellulose, hemicellulose, and lignin: an overview, Int. Microbiol. 5 (2002) 53-63.

[3] C. Sant'Anna, W. De Souza, M. Brienzo, The influence of the heterogeneity, physicochemical and structural properties on the recalcitrance and conversion of sugarcane bagasse, in: Sugarcane: Production, Consumption and Agricultural Management Systems, first ed., Nova Science Publishers, 2014, pp. 1-33.

[4] G. Siqueira, A.M.F. Milagres, W. Carvalho, G. Koch, A. Ferraz, Topochemica distribution of lignin and hydroxycinnamic acids in sugar-cane cell walls and its correlation with the enzymatic hydrolysis of polysaccharides, Biotechnol Biofuel 4 (2011) 7.
[5] D. Fengel, G. Wegener, Wood: Chemistry, Ultrastructure, Reactions, 1984. Berlin, New York.

[6] M. Brienzo, S. Ferreira, M.P. Vicentim, W. De Souza, C. Sant'Anna, Comparison study on the biomass recalcitrance of different tissue fractions of sugarcane culm, Bioenerg. Res. 7 (2014) 1454-1465.

[7] M. Brienzo, L. Tyhoda, Y. Benjamin, J. Görgens, Relationship between physicochemical properties and enzymatic hydrolysis of sugarcane bagasse varieties for bioethanol production, New Biotechnol. 32 (2015) 253-262.

[8] J. Zhang, M. Siika-aho, M. Tenkanen, L. Viikari, The role of acetyl xylan esterase in the solubilization of xylan and enzymatic hydrolysis of wheat straw and giant reed, Biotechnol. Biofuels 4 (2011) 60.

[9] X. Pan, N. Gilkes, J.N. Saddler, Effect of acetyl groups on enzymatic hydrolysis of cellulosic substrates, Holzforschung 60 (2006) 398-401.

[10] Y. Benjamin, H. Cheng, J.F. Görgens, Evaluation of bagasse from different varieties of sugarcane by diluteacid pretreatment and enzymatic hydrolysis, Ind. Crops Prod. 51 (2013) 7-18.

[11] P.F. Vena, M. García-Aparicio, M. Brienzo, J.F. Görgens, T. Rypstra, Effect of alkaline hemicellulose extraction on kraft pulp fibers from Eucalyptus grandis, J. Wood Chem. Technol. 33 (2013) 157-173.

[12] R. Chandra, S. Ewanick, C. Hsieh, J.N. Saddler, The characterization of pretreated lignocellulosic substrates prior to enzymatic hydrolysis, part 1: a modified Simons' staining technique, Biotechnol. Prog. 5 (2008) 1178-1185.

[13] A. Sluiter, B. Hames, R. Ruiz, C. Scarlata, J. Sluiter, D. Templeton, Compositiona analysis of lignocellulosic feedstocks 1 . Review and description of methods, J. Agric. Food Chem. 58 (2010) 9043-9053.

[14] F. Masarin, D.B. Gurpilhares, D.C.F. Baffa, M.H.P. Barbosa, W. Carvalho, A. Ferraz, A.M.F. Milagres, Chemical composition and enzymatic digestibility of sugarcane clones selected for varied lignin content, Biotechnol. Biofuels 4 (2011) 55.

[15] M. Brienzo, A.F. Siqueira, A.M.F. Milagres, Search for optimum conditions of sugarcane bagasse hemicellulose extraction, Biochem. Eng. J. 46 (2009) 199-204.

[16] J.P.I. Bekker, Genetic Manipulation of the Cell Wall Composition of Sugarcane (Ph.D. thesis), University of Stellenbosch, 2007.

[17] L.J. Jönsson, C. Martin, Pretreatment of lignocellulose: formation of inhibitory by-products and strategies for minimizing their effects, Bioresour. Technol. 199 (2016) 103-112.

[18] J. Boucher, C. Chirat, D. Lachenal, Comparison between acid hydrolysis and two-step autohydrolysis for hemicellulosic ethanol production, Cellul. Chem. Technol. 49 (2015) 303-308.

[19] Y. Benjamin, H. Cheng, J.F. Görgens, Optimization of dilute sulfuric acid pretreatment to maximize combined sugar yield from sugarcane bagasse for ethanol production, Appl. Biochem. Biotechnol. 172 (2014) 610-630.

[20] M. Brienzo, E.M. Silva, A.M.F. Milagres, Degradation of eucalypt waste components by Lentinula edodes strains detected by chemical and near-infrared spectroscopy methods, Appl. Biochem. Biotechnol. 141 (2007) 37-50.

[21] X.F. Sun, F. Xu, R.C. Sun, P. Fowler, M.S. Baird, Characteristics of degraded cellulose obtained from steam-exploded wheat straw, Carbohyd. Res. 340 (2005) 97-106.

[22] A.J. Mitchell, FTIR spectroscopic studies of the reactions of wood and lignin model compounds with inorganic agents, Wood Sci. Technol. 27 (1993) 69-80.

[23] V.S. Chang, M.T. Holtzapple, Fundamental factors affecting biomass enzymatic reactivity, Appl. Biochem. Biotechnol. 84 (2000) 5-37.

[24] M. Brienzo, Y. Abud, S. Ferreira, R.C.N.R. Corrales, V.S. Ferreira-Leitão, W. De Souza, C. Sant'Anna, Characterization of anatomy, lignin distribution, and response to pretreatments of sugarcane culm node and internode, Ind. Crop Prod. 84 (2016) 305-313.

[25] F. Guo, W. Shi, W. Sun, X. Li, F. Wang, J. Zhao, Y. Qu, Differences in the adsorption of enzymes onto lignins from diverse types of lignocellulosic biomass and the underlying mechanism, Biotechnol. Biofuels 14 (2014) 7-38.

[26] A.F. Torres, T. van der Weijde, O. Dolstra, R.G.F. Visser, L.M. Trindade, Effect of maize biomass composition on the optimization of dilute-acid pretreatments and enzymatic saccharification, Bioenerg. Res. 6 (2013) 1038-1051.

[27] X. Yu, J.L. Minor, R.H. Atalla, Mechanism of action of Simons' stain, Tappi J. 78 (1985) 175-180.

[28] C.A. Mooney, S.D. Mansfield, M.G. Touhy, J.N. Saddler, The effect of initial pore volume and lignin content on the enzymatic hydrolysis of softwoods, Bioresour. Technol. 64 (1998) 113-119.

[29] M.A.T. Hansen, J.B. Kristensen, C. Felby, H. Jørgensen, Pretreatment and enzymatic hydrolysis of wheat straw (Triticum aestivum L.) - the impact of lignin relocation and plant tissues on enzymatic accessibility, Bioresour. Technol. 102 (2011) 2804-2811.

[30] X. Yu, R.H. Atalla, A staining technique for evaluating the pore structure variations of microcrystalline powders, Powder Technol. 98 (1998) 135-138.

[31] B.W. Koo, T.H. Treasure, H. Jameel, R.B. Philips, H.M. Chang, S. Park, Reduction of enzyme dosage by oxygen delignification and mechanical refining for enzymatic hydrolysis of green liquor-pretreated hardwood, Appl. Biochem. Biotechnol. 165 (2011) 832-844.

[32] X. Meng, M. Foston, J. Leisen, J. DeMartini, C.E. Wyman, A.J. Ragauskas, Determination of porosity of lignocellulosic biomass before and after pretreatment by using Simons' stain and NMR techniques, Bioresour. Technol. 144 (2013) 467-476.

[33] J. Wallace, M. Brienzo, M. Garcia-Aparicio, J. Görgens, Lignin enrichment and enzyme deactivation as the root cause of enzymatic hydrolysis slowdown of 
steam pretreated sugarcane bagasse, New Biotechnol. 33 (2016) 361-371.

[34] D.S. Burns, H. Ooshima, A.O. Converse, Surface area of pretreated lignocellulosics as a function of the extent of enzymatic hydrolysis, Appl. Biochem. Biotechnol. 20 (1989) 79-94.

[35] C. Santi-Junior, A.M.F. Milagres, A. Ferraz, W. Carvalho, The effects of lignin removal and drying on the porosity and enzymatic hydrolysis of sugarcane bagasse, Cellulose 20 (2013) 3165-3177.

[36] J.M. Martinez, J. Reguant, M.A. Montero, D. Montane, J. Salvado, X. Farriol, Hydrolytic pretreatment of softwood and almond shells. Degree of polymerization and enzymatic digestibility of the cellulose fraction, Ind. Eng. Chem.
Res. 36 (1997) 688-696.

37] B. Hallac, A.J. Ragauskas, Analyzing cellulose degree of polymerization and its relevancy to cellulosic ethanol, Biofuels, Bioprod. Bioref. 5 (2011) 215-225.

[38] A.P. Sinitsyn, A.V. Gusakov, E.Y. Vlasenko, Effect of structural and physicochemical features of cellulosic substrates on the efficiency of enzymatic hydrolysis, Appl. Biochem. Biotechnol. 30 (1991) 43-59.

[39] E.M. Vallejos, E.F. Felissia, J. Kruyeniski, C.M. Area, Kinetic study of the extraction of hemicellulosic carbohydrates from sugarcane bagasse by hot water treatment, Ind. Crop Prod. 67 (2015) 1-6. 